ISSN 1392-3196 / e-ISSN 2335-8947

Zemdirbyste-Agriculture, vol. 104, No. 2 (2017), p. 173-178

DOI 10.13080/z-a.2017.104.022

\title{
Fusarium mycotoxin contamination and co-occurrence in Slovak winter wheat grains
}

\author{
Magdaléna LACKO-BARTOŠOVÁ ${ }^{1}$, Jaroslav REMŽA², Lucia LACKO-BARTOŠOVÁ ${ }^{3}$ \\ ${ }^{1}$ Slovak University of Agriculture in Nitra \\ Tr. A. Hlinku 2, 94976 Nitra, Slovak Republic \\ E-mail: magdalena.lacko-bartosova@uniag.sk \\ ${ }^{2}$ State Veterinary and Food Administration of the Slovak Republic \\ Botanická 17, 84213 Bratislava, Slovak Republic \\ ${ }^{3}$ University of Economics in Bratislava \\ Dolnozemská cesta 1, 85235 Bratislava, Slovak Republic
}

\begin{abstract}
The contamination of unprocessed winter wheat grain by mycotoxins was detected on the territory of the Slovak Republic with the focus on primary producers, after the harvest in 2009-2010, 2010-2011 and 2011-2012 growing periods. Mycotoxin levels were determined by high performance liquid chromatography (HPLC) methods. Deoxynivalenol (DON) was the most common Fusarium toxin, detected in $85 \%$ of samples, $2 \%$ of samples exceeded the maximum level set by Regulation (EC) 1881/2006. Nivalenol (NIV) was detected in $63 \%$ of samples, T-2 toxin - in 73\% and HT-2 toxin - in 79\%. The mean concentration of DON was $368.4 \mu \mathrm{g} \mathrm{kg}^{-1}$, for NIV $-34.8 \mu \mathrm{g}$ $\mathrm{kg}^{-1}$, for T-2 toxin $-38.2 \mu \mathrm{g} \mathrm{kg}^{-1}$ and for HT-2 toxin $-29.9 \mu \mathrm{g} \mathrm{kg}^{-1}$. Co-occurrence of DON with NIV was detected in $15.5 \%$ of positive samples and their co-occurrence with other mycotoxins represented additional $7.35 \%$. Cooccurrence of DON with zearalenone (ZEA) was detected in $25.9 \%$ of positive samples.

To prevent the occurrence of mycotoxins at levels considered harmful to human health, a number of measures are needed at different levels, from good agricultural practices, breeding for resistance, to adequate legislation, methods and programs for food control that influence food security.
\end{abstract}

Key words: co-occurrence, type A and B trichothecenes, winter wheat, zearalenone.

\section{Introduction}

Wheat is the most popular cereal grown in the European Union and an important nutrient source for humans and animals. Cereals account for one-quarter of the EU crop production value and for one-eighth of the total value of its agricultural products (Stanciu et al., 2015). Wheat is often infested by Fusarium species producing mycotoxins, which may pose health risk to humans and animals (Lindblad et al., 2013). Fusarium head blight is one of the most severe diseases of small grain cereals across the world and it is predominantly caused by different Fusarium species and Microdochium nivale (Blandino et al., 2012). FAO estimated that approximately $25 \%$ of the cereals produced in the world are contaminated by mycotoxins, but perhaps this value is closer to $50 \%$, if one takes into account emerging mycotoxins of which limited data have been available so far (Stanciu et al., 2015).

Fusarium species can produce a wide range of mycotoxins, including trichothecenes, zearalenone (ZEA) and fumonisins. Trichothecenes are divided into type A, including T-2 and HT-2 toxins, and type B trichothecenes, including deoxynivalenol (DON) and nivalenol (NIV). The most common trichothecene found in cereals is DON that is produced predominantly by $F$. graminearum and F. culmorum. Isolates of these species are either DON or NIV producers. Type A trichothecenes are produced mainly by $F$. sporotrichioides and $F$. langsethiae. M. nivale does not produce any mycotoxins (Wilson et al., 2004; Miller, 2008). The most important mycotoxins in cereals in Northern Europe are most likely the trichothecenes as well as ZEA (Nordkvist, Häggblom, 2014). ZEA is a non-steroidal oestrogenic mycotoxin, mainly produced by a variety of Fusarium fungi, which are common soil fungi, prevalent in temperate and warm countries. ZEA, and the metabolite zearalenol, is absorbed through gastrointestinal tract and excreted relatively rapidly in feces, urine, to small extent in milk (Bennett, Klich, 2003; Mostrom, 2011).

Please use the following format when citing the article:

Lacko-Bartošová M., Remža J., Lacko-Bartošová L. 2017. Fusarium mycotoxin contamination and co-occurrence in Slovak winter wheat grains. Zemdirbyste-Agriculture, 104 (2): 173-178 DOI 10.13080/z-a.2017.104.022 
The predominant adverse effects of ZEA and its metabolites are related to estrogenic activity like: changes in the serum levels of progesterone and estradiol, alterations in the reproductive tract, decreased fertility, increased embryolethal resorptions. ZEA has been shown to be immunotoxic, genotoxic, nephrotoxic with high potential of carcinogenicity; ZEA and its derivates are classified as endocrine disruptor chemicals (Zinedine et al., 2007; Mostrom, 2011; Haschek, Voss, 2013).

Trichothecenes are small molecules that can move passively through cell membranes, can be absorbed by gastrointestinal and respiratory tracts, as well as by skin. Trichothecenes have multiple toxic effects on eukaryotic cells, the most important being the inhibition of protein synthesis, RNA and DNA synthesis, induction of programmed cell death or apoptosis, they can produce alteration of membrane structure and mitochondrial function, stimulation of lipid peroxidation, etc. (McCormic et al., 2011; Pinton et al., 2012; MarroquínCardona et al., 2014). Different studies have shown that trichothecenes can cause adverse effects in humans consuming grain-based food, chronic exposure can lead to anorexia, nausea, growth retardation, neuroendocrine changes, immunosuppression, gastroenteritis, immune modulations, gastrointestinal toxicity, exacerbation of infections (Pestka, 2008; Streit et al., 2012; Marin et al., 2013). Acute toxicosis results in a shock-like response, e.g., diarrhea, vomiting and hemorrhage, including mortality at higher doses (Pestka, 2007).

The European Commission has set maximum tolerated levels for several mycotoxins in cereals and also the methods of sampling and analysis of mycotoxins: Regulation (EC) 1881/2006 consolidated version by Regulation (EC) 1126/2007, Regulation (EC) 629/2008, Regulation (EC) 165/2010, Regulation (EC) 401/2006 and Recommendation (EC) 165/2013. In unprocessed wheat, the maximum level for DON is $1250 \mu \mathrm{g} \mathrm{kg}^{-1}$, for ZEA it is $100 \mu \mathrm{g} \mathrm{kg}^{-1}$. A recommendation on monitoring the levels of T-2 and HT-2 toxins in unprocessed wheat has been adopted with maximum levels for the sum of these two toxins of $100 \mu \mathrm{g} \mathrm{kg}^{-1}$.
A provisional tolerable daily intake (TDI) for DON was set in 2002 by the Scientific Committee for Food at $1 \mu \mathrm{g} \mathrm{kg}^{-1}$ body weight (b.w.) per day. In 2010 the Joint FAO/WHO Expert Committee on Food Additives (JECFA) extended it to the group of DON and its acetyl derivatives and also derived an acute reference dose at $8 \mu \mathrm{g} \mathrm{kg}^{-1} \mathrm{~b}$.w. The exposure assessments conducted to date at national or European level concluded that consumers and young children were exposed to DON at levels close to or even higher than the TDI (EFSA, 2013).

The Panel on Contaminants in the Food Chain established a tolerable daily intake for ZEA at $0.25 \mu \mathrm{g} \mathrm{kg}^{-1}$ b.w. (EFSA, 2011 a). The ZEA average daily dietary exposures ranged among adults from 4 to $20 \mathrm{ng} \mathrm{kg}^{-1}$ b.w. per day. Small children had the highest average daily dietary exposures ranging from 6 to $55 \mathrm{ng} \mathrm{kg}^{-1}$ b.w. per day. Main contributors to the dietary exposure were found to be maize, wheat and the corresponding products (SCOOP, 2003).

The aim of this work was to evaluate the occurrence of Fusarium mycotoxins (DON, ZEA, NIV, T-2 and HT-2 toxins) in winter wheat grains with focus on primary producers storage facilities on the territory of the Slovak Republic after the harvest in growing periods 2009-2010, 2010-2011 and 2011-2012. The distribution, levels and co-occurrence of these mycotoxins were studied to assess their possible effects on human health.

\section{Materials and methods}

Winter wheat unprocessed grain samples were taken according to Regulation (EC) 401/2006 which establishes the criteria for the sampling for the control of the levels of mycotoxins, within the whole food chain. The total number of samples within three years' (20092012) period was 495. Sampling, subdivision of lots, sublots and sample weight met the criteria described in Tables 1 and 2.

Samples were milled, thoroughly mixed to achieve complete homogenisation. The concentration of mycotoxins was detected in winter wheat samples by using high performance liquid chromatography (HPLC).

Table 1. Subdivision of lots into sublots depending on product and lot weight (Regulation (EC) 401/2006)

\begin{tabular}{ccccc}
\hline Commodity & $\begin{array}{c}\text { Lot weight } \\
\mathrm{t}\end{array}$ & $\begin{array}{c}\text { Weight or number of } \\
\text { sublots }\end{array}$ & $\begin{array}{c}\text { Number of } \\
\text { incremental samples }\end{array}$ & $\begin{array}{c}\text { Aggregate sample } \\
\text { weight } \\
\mathrm{kg}\end{array}$ \\
\hline Cereals and & $\geq 1500$ & $500 \mathrm{t}$ & 100 & 10 \\
cereal products & $>300<1500$ & 3 sublots & 100 & 10 \\
& $\geq 50 \leq 300$ & $100 \mathrm{t}$ & 100 & 10 \\
& $<50$ & - & $3-100^{*}$ & $1-10$ \\
\hline
\end{tabular}

* - depending on the lot weight - in Table 2

Table 2. Number of incremental samples depending on lot weight

\begin{tabular}{ccc}
\hline $\begin{array}{c}\text { Lot weight } \\
\mathrm{t}\end{array}$ & $\begin{array}{c}\text { Number of } \\
\text { incremental samples }\end{array}$ & $\begin{array}{c}\text { Aggregate sample } \\
\text { weight } \\
\mathrm{kg}\end{array}$ \\
\hline$\leq 0.05$ & 3 & 1 \\
$>0.05 \leq 0.5$ & 5 & 1 \\
$>0.5 \leq 1$ & 10 & 1 \\
$>1 \leq 3$ & 20 & 2 \\
$>3 \leq 10$ & 40 & 4 \\
$>10 \leq 20$ & 60 & 6 \\
$>20 \leq 50$ & 100 & 10 \\
\hline
\end{tabular}

Zearalenone (ZEA) determination method. Preparation of the sample: a total of $20 \mathrm{~g}$ of the ground samples were extracted with $100 \mathrm{ml}$ extraction solvent acetonitrile-water (75/25, v/v) and homogenized with ULTRA TURRAX ${ }^{\circledR}$ Tube Drive control (IKA ${ }^{\circledR}$, Germany). The suspension was centrifuged at $1600 \mathrm{~g}$ for $10 \mathrm{~min}$, filtered through filter paper and purified on multifunctional column MycoSep ${ }^{\circledR} 26$ AflaZon+ (Romer Labs, Austria). Eight $\mathrm{ml}$ of supernatant was transferred to the glass tube (acidified with $80 \mu \mathrm{l}$ acetic acid) and pushed all through MycoSep ${ }^{\circledR} 226$ column. Removed $4 \mathrm{ml}$ and evaporated to dryness. Residues were redissolved in $400 \mu 1$ mobile phase and injected into HPLC. 
HPLC conditions: HPLC/FLD system consisted of an Agilent 1260 (Agilent, USA), equipped with Symmetry ${ }^{\circledR}$ C18 $5 \mu \mathrm{m} 4.6 \times 250 \mathrm{~mm}$ column, degasser, binary pump, multisampler, column thermostat and fluorescence detector. The mobile phase consisted of acetonitrile-water-acetic acid (51/47/2, v/v/v). All separations were carried out at $40^{\circ} \mathrm{C}$ applying a flow of $1 \mathrm{ml} \mathrm{min}{ }^{-1}$. The injection volume was $50 \mu \mathrm{l}$. ZEA was detected with fluorescence detector which was set for excitation wavelength of $274 \mathrm{~nm}$ and emission wavelength of $455 \mathrm{~nm}$.

Deoxynivalenol (DON), nivalenol (NIV), T-2 and HT-2 determination method. A total of $20 \mathrm{~g}$ of the ground samples were extracted with $100 \mathrm{ml}$ extraction solvent acetonitrile-water $(84 / 16, \mathrm{v} / \mathrm{v})$ and homogenized with ULTRA TURRAX ${ }^{\circledR}$ Tube Drive control (IKA ${ }^{\circledR}$, Germany). The suspension was centrifuged at $2500 \mathrm{~g}$ for $10 \mathrm{~min}$, filtered through a filter paper and purified on immunoaffinity column Mycosep ${ }^{\circledR} 227$ Trich+ (Romer Labs, Austria) for DON, T-2 and HT-2 toxins. Mycosep ${ }^{\circledR} 230$ (Romer Labs, Austria) was used for NIV. Eight $\mathrm{ml}$ of supernatant was transferred to the glass tube and pushed all through immunoaffinity column. Removed $4 \mathrm{ml}$ and evaporated to dryness. Residues were redissolved in $400 \mu \mathrm{l}$ mobile phase and injected to HPLC.

HPLC conditions: HPLC/UV system consisted of an Agilent 1260 (Agilent, USA), equipped with Symmetry $^{\circledR}$ C18 $5 \mu \mathrm{m} 4.6 \times 250 \mathrm{~mm}$ column, degasser, binary pump, multisampler, column thermostat and diode-array (DAD) detector. The mobile phase consisted of components $\mathrm{A}-0.1 \%$ formic acid and $\mathrm{B}$ - acetonitrile, with flow rate $1 \mathrm{ml} \mathrm{s}^{-1}$. Binary gradient was as follows: $0-5 \mathrm{~min} 10 \% \mathrm{~B}$ and $5-20 \mathrm{~min} 10-60 \% \mathrm{~B}$. All separations were carried out at $40^{\circ} \mathrm{C}$ applying a flow of $1 \mathrm{ml} \mathrm{min}^{-1}$.

The injection volume was $50 \mu \mathrm{l}$. DON and NIV were detected with DAD detector which was set for a wavelength of $218 \mathrm{~nm}$. T-2 and HT-2 were detected with DAD detector which was set for a wavelength of $225 \mathrm{~nm}$.

Methods of analysis used were in accordance with the provisions of items 1 and 2 of Annex III of Regulation (EC) 882/2004.

Obtained data was initially subjected to descriptive statistics (median, mean and range); data were processed statistically using software STATISTICA, version 10.0. Due to the fact that different numbers of samples were analysed for each year, it was necessary to carry out Bartlett's test of homogeneity. Duncan's test of contrasts was used for unbalanced numbers of the measurements.

\section{Results and discussion}

In winter wheat samples, five different mycotoxins produced by fungi from genus Fusarium sp. were detected. Numbers of analysed samples, samples under and over the limits of detection are presented in Table 3.

Table 3. Overview of analysed mycotoxins in winter wheat

\begin{tabular}{ccccccc}
\hline Mycotoxin & $\begin{array}{c}\text { No. of } \\
\text { samples }\end{array}$ & $\begin{array}{c}\text { Limit of } \\
\text { detection* } \\
\mu \mathrm{g} \mathrm{kg}^{-1}\end{array}$ & $\begin{array}{c}\text { No. under } \\
\text { limit of } \\
\text { detection }\end{array}$ & $\begin{array}{c}\text { No. over } \\
\text { limit of } \\
\text { detection }\end{array}$ & $\begin{array}{c}\text { Maximum } \\
\text { level } \\
\mu \mathrm{g} \mathrm{kg}^{-1}\end{array}$ & $\begin{array}{c}\text { No. over } \\
\text { maximum level }\end{array}$ \\
\hline DON & 189 & 20 & 28 & 161 & 1250 & 4 \\
ZEA & 175 & 1 & 62 & 113 & 100 & 0 \\
NIV & 80 & 20 & 30 & 50 & 0 & 0 \\
T-2 & 70 & 1 & 19 & 51 & 0 ** & 0 \\
HT-2 & 66 & 1 & 14 & 52 & $0 * *$ & 0 \\
\hline
\end{tabular}

* - according to Regulation (EC) 1881/2006; ** - the sum of T-2 and HT-2 set at $100 \mu \mathrm{g} \mathrm{kg}^{-1}$ according to Recommendation (EC) $165 / 2013$

DON was detected in 189 samples, the content of DON was in 161 samples $(85 \%)$ over the limit of detection, and 4 samples exceeded the maximum level set by Regulation (EC) 1881/2006 what represented 2\% of all analysed samples. Occurrence of T-2 and HT-2 toxins was also high; number of samples over detection limits was $73 \%$ for T-2 and $79 \%$ for HT-2 toxin. ZEA was detected in $65 \%$ of samples and NIV in $63 \%$. In all cases, concentration of ZEA did not exceed the limit set in legislation. The average content of trichothecene DON was significantly affected by year of cultivation (Table 4). Overall concentrations of DON in wheat samples in 2009-2010 was considered as low, compared to the years 2010-2011 and 2011-2012 (significant).

Table 4. Summary of wheat samples analysed for DON contamination by year

\begin{tabular}{ccccc}
\hline Year & $\begin{array}{c}\text { No. of positive samples / } \\
\text { total No. }\end{array}$ & $\begin{array}{c}\text { Mean } \\
\mu \mathrm{g} \mathrm{kg}{ }^{-1}\end{array}$ & $\begin{array}{c}\text { Median } \\
\mu \mathrm{kg}^{-1}\end{array}$ \\
\hline $2009-2010$ & $55 / 70$ & $144.77 \mathrm{a}$ & 56.25 & $20-2220.0$ \\
$2010-2011$ & $70 / 77$ & $481.23 \mathrm{~b}$ & 343.00 & $20-2483.2$ \\
$2011-2012$ & $36 / 42$ & $300.16 \mathrm{~b}$ & 97.47 & $20-2651.8$ \\
\hline
\end{tabular}

Note. The same letters in the column indicate homogeneous groups at $P=0.05$.

Higher content of mycotoxins in 2010-2011 and 2011-2012 confirmed the theory of higher incidence of mycotoxins, especially in more humid areas or growing seasons with rainy weather, mainly during the flowering of the cereals. Wheat samples were analysed on the trichothecene mycotoxins types B (DON, NIV) and A (T-2, HT-2). The results are shown in Table 5.

Trichothecene DON is probably the best known and the most common mycotoxin contaminant of food and feed grains. On the basis of our results it should be 
Table 5. Positive samples and range of concentration of type A and B trichothecenes in wheat

\begin{tabular}{cccccc}
\hline $\begin{array}{c}\text { Trichothecenes, } \\
\text { type }\end{array}$ & Mycotoxin & $\begin{array}{c}\text { No. of positive } \\
\text { samples } / \\
\text { total No. }\end{array}$ & $\begin{array}{c}\text { Mean } \\
\mu \mathrm{g} \mathrm{kg}{ }^{-1}\end{array}$ & $\begin{array}{c}\text { Median } \\
\mu \mathrm{kg}^{-1}\end{array}$ & $\begin{array}{c}\text { Concentration } \\
\text { range } \\
\mu \mathrm{kg}^{-1}\end{array}$ \\
\hline \multirow{2}{*}{$\mathrm{B}$} & DON & $161 / 189$ & 368.4 & 149.0 & $20-2651.8$ \\
& NIV & $51 / 80$ & 34.8 & 26.3 & $5-181.3$ \\
\hline \multirow{2}{*}{$\mathrm{A}$} & T-2 & $51 / 70$ & 38.2 & 25.0 & $1-78.1$ \\
& HT-2 & $48 / 66$ & 29.9 & 21.8 & $1-75.0$ \\
\hline
\end{tabular}

pointed out that particularly DON could be regarded as an indicator of the overall mycotoxin contamination within the conditions of the Slovak Republic. The mean concentration of DON achieved $368.4 \mu \mathrm{g} \mathrm{kg}^{-1}$. Next to DON, there are other masked forms of DON, deoxynivalenol-3-glucoside (D3G) or 3(15)-acetyldeoxynivalenol (3(15)-ADON), but changes among these forms are still insufficiently known (Maresca, 2013). Pazderu et al. (2016) suggested high importance of evaluating not only DON, but all DON forms simultaneously. Fusarium head blight tolerant cultivars may contain a high proportion of grain which is apparently healthy, but contain excessive DON levels. Such tolerant cultivars may present a potential health hazard of whole - grain flour (Lešnik et al., 2014).

The mean concentration of NIV was $34.8 \mu \mathrm{g} \mathrm{kg}^{-1}$; it varied in the range from 5 to $181.3 \mu \mathrm{g} \mathrm{kg}^{-1}$. It can be assumed that trichothecene NIV co-occurs regularly together with DON. The European Commission does not have yet sufficient database of measured levels of NIV in European cereals and is considering whether to set a separate limit for NIV.

In our study, there were no fumonisins determined in the wheat samples. T-2 toxin is the most toxic of Fusarium trichothecenes, although is less frequent than DON, concentration and occurrence of T-2 toxin was far lower than DON. The mean concentration of T-2 toxin was $38.2 \mu \mathrm{g} \mathrm{kg}^{-1}$ and varied in the range of $1-78.1 \mu \mathrm{g} \mathrm{kg}^{-1}$, the mean concentration of HT-2 was lower, $29.9 \mu \mathrm{g} \mathrm{kg}^{-1}$ with the range from 1 to $75.0 \mu \mathrm{g} \mathrm{kg}^{-1}$.

Similar concentrations of T-2 and HT-2 toxins were obtained in the Czech Republic; occurrence of HT-2 toxin was about three times more frequent than T-2 toxin (Pospíchalová, 2013). In the same study, DON was the predominant mycotoxin detected in $50 \%$ of wheat samples, followed by ZEA and ochratoxin A. A relationship between T-2 and HT-2 toxins has been investigated in several studies and in general it has been found to be strong. This relationship is expected because T-2 toxin is metabolized to HT-2 toxin (EFSA, $2011 \mathrm{~b}$ ).

ZEA concentration in wheat grain showed the same trend of incidence in each year as DON, although its concentration was lower, fluctuating between 1 to $288 \mu \mathrm{g}$ $\mathrm{kg}^{-1}$. The reason is probably the fact that ZEA producers are the same species of Fusarium, which are $F$. graminearum, $F$. culmorum. Besides these, the producers of this toxin are also $F$. equiseti and F. cerealis (Bottalico, Perrone, 2002). An important aspect for Fusarium genus is that the same mycotoxin can be produced by different Fusarium species and one species can produce various mycotoxins at once (Stanciu et al., 2015). In Lithuanian conditions, $F$. graminearum, F. culmorum and $F$. poae were identified as species capable of producing mycotoxins DON and NIV in wheat grain (Suproniene et al., 2016).

Most mycotoxins can act alone, but some also act synergistically with others causing more severe effects to human health. As was found in the surveys by Ellner (2001), co-contamination of mycotoxins can be discovered continuously, especially in highly contaminated samples. Survey presented that over $23 \%$ of the samples were contaminated with at least two mycotoxins. The problem of co-occurrence of Fusarium mycotoxins is a recurring feature, raising the question of interactions, synergistic or antagonistic actions in the manifestation of toxicity (Streit et al., 2012).

Considerable attention is paid to the toxic effects of simultaneous exposure of multiple mycotoxins to animals. Speijers and Speijers (2004) and Gajecki et al. (2007) have reported that synergistic toxic effects were in many cases confirmed. For this reason, some mycotoxins are currently the subject of food legislation, but also the subject of studies concerning their common occurrence in the primary products of plant origin. Results of numerous studies indicate that the extent of the risk of contamination of feed/food by several mycotoxins depends on the level and type of mycotoxins, species, age of animals/people and their health, interactions of mycotoxins can be complementary, synergistic or antagonist (Njobeh et al., 2010).

The results in the Slovak Republic demonstrated that in many cases, as shown in Table 6, was the cooccurrence of several mycotoxins confirmed.

Table 6. Co-occurrence of mycotoxins in winter wheat samples $(\mathrm{n}=258)$

\begin{tabular}{cc}
\hline Mycotoxins & $\begin{array}{c}\text { Positive samples No. } \\
(\%)\end{array}$ \\
\hline DON + NIV & $40(15.5 \%)$ \\
DON + NIV + T2 + HT2 & $1(0.38 \%)$ \\
DON + ZEA & $31(12.01 \%)$ \\
DON + ZEA + NIV & $17(6.59 \%)$ \\
DON + ZEA + NIV + T2 + HT2 & $1(0.38 \%)$ \\
DON + ZEA + T2 + HT2 & $18(6.97 \%)$ \\
\hline
\end{tabular}

Trichothecene NIV occurred regularly together with other mycotoxins, co-occurrence was detected in $15.5 \%$ of positive samples with DON and in additional $7.35 \%$ of samples except DON also ZEA, T-2 and HT-2 toxins were detected. We can conclude that in the conditions of the Slovak Republic, in wheat grain the co-occurrence of DON and NIV can be expected. This highlights that it is reliable to assume and to control the occurrence of NIV depending on the occurrence of DON. Regression analysis of DON and NIV showed very high correlation $\left(r_{\mathrm{yx}}=0.97\right)$ with regression equation $\mathrm{y}=-46.289+4.959 \mathrm{x}$, what should presume that an increase of NIV about $1 \mu \mathrm{g} \mathrm{kg}^{-1}$ increased the content of DON about $4.959 \mu \mathrm{g} \mathrm{kg}^{-1}$. Co-occurrence of DON with ZEA was detected in $25.9 \%$ of positive samples but no correlation between DON and ZEA levels was found $(r=-0.03)$. 
In our experiments, correlation between DON and toxins HT-2 and T-2 was not determined. This agrees with the known taxonomy of the Fusarium genus, which indicates that T- 2 and HT- 2 are produced by various strains of Fusarium - having different environmental requirements from those that produce DON (Edwards, 2009).

It is expected, as a consequence of climate change, that the levels of mycotoxins will increase, the shift from the previous dominance of $F$. graminearum and $F$. culmorum has already been reported by several authors. In addition to the regulated toxins, wheat contamination by NIV as well as by so-called 'emerging mycotoxins' including beauvericin (BEA), moniliformin $(\mathrm{MON})$ and enniatins (ENNs) has been reported (Miller, 2008; Lindblad et al., 2013). However, no data on their prevalence have been presented for Slovakia.

\section{Conclusions}

Food safety and food quality are very important issues in the context of international trade. Wheat is the most cultivated and consumed cereal which is often infected by Fusarium species producing mycotoxins, which may pose health risks to humans.

Investigation of unprocessed winter wheat grains with the focus on primary producers' storage facilities (storage bins, silos, rooms) in the Slovak Republic for the Fusarium mycotoxins demonstrated their occurrence in most of the samples:

1. Deoxynivalenol (DON) was the most common Fusarium toxin of winter wheat grains.

2. Occurrence of mycotoxins was in order DON with $85 \%$ of samples over the limit of detection, HT-2 toxin with $79 \%$, T-2 toxin with $73 \%$, zearalenone (ZEA) was detected in $65 \%$ and nivalenol (NIV) in $63 \%$ of the samples.

3. Co-occurrence of several mycotoxins was detected; the co-occurrence of DON and NIV, but also DON and ZEA can be expected.

4. High correlation between the contents of DON and NIV was found; an increase of NIV about $1 \mu \mathrm{g} \mathrm{kg}^{-1}$ increased the content of DON about $4.959 \mu \mathrm{g} \mathrm{kg}^{-1}$. On the contrary, no correlation between the contents of DON and ZEA was detected.

\section{Acknowledgments}

The research presented in this paper was supported by the project ITEBIO "Support and innovations of a special and organic products technologies for human healthy nutrition" ITMS: 26220220115 , implemented under Operational Programme Research and Development.

Received 17092016 Accepted 24032017

\section{References}

Bennett J. W., Klich M. 2003. Mycotoxins. Clinical Microbiology Reviews. 16 (3): 497-516 https://doi.org/10.1128/CMR.16.3.497-516.2003

Blandino M., Haidukowski M., Pascale M., Plizzari L., Scudellari D., Reyneri A. 2012. Integrated strategies for the control of Fusarium head blight and deoxynivalenol contamination in winter wheat. Field Crops Research, 133: 139-149 https://doi.org/10.1016/j.fcr.2012.04.004
Bottalico A., Perrone G. 2002. Toxigenic Fusarium species and mycotoxins associated with head blight in small-grain cereals in Europe. European Journal of Plant Pathology, 108: 611-624 https://doi.org/10.1023/A:1020635214971

Edwards S. G. 2009. Fusarium mycotoxin content of UK organic and conventional wheat. Food Additives and Contaminants. 26 (4): 496-506 https://doi.org/10.1080/02652030802530679

EFSA 2011 (a). Scientific opinion on the risks for public health related to the presence of zearalenone in food. EFSA Journal. 9 (6): 2197 https://doi.org/10.2903/j.efsa.2011.2197

EFSA 2011 (b). Scientific opinion on the risks for animal and public health related to the presence of T-2 and HT-2 toxin in food and feed. EFSA Journal. 9 (12): 2481 https://doi.org/10.2903/j.efsa.2011.2481

EFSA 2013. Deoxynivalenol in food and feed: occurrence and exposure. EFSA Journal. 11 (10): 3379 https://doi.org/10.2903/j.efsa.2013.3379

Ellner F. M. 2001. Fusarium toxins in cereals - results from eight German Federal States in 2000. Mycotoxin Research. 17 (1): 41-44 https://doi.org/10.1007/BF03036709

Gajecki M., Zielonka L., Obremski K., Jakimiuk E., Gajecka M. 2007. Multi-mycotoxicosis. Environmental Biotechnology, 3: $25-29$

Haschek W. M., Voss K. A. 2013. Mycotoxins. Haschek W. M. et al. (eds.). Handbook of toxicologic pathology, p. $1187-1258$

Lešnik M., Vajs S., Kramberger B., Žeriav M., Zemlič A., Simončič A., Kolmanič A. 2014. Fusarium infected grain removal efficacy in cleaning wheat grain prior to milling. Zemdirbvste-Agriculture. 101 (3): 285-294 https://doi.org/10.13080/z-a.2014.101.037

Lindblad M., Gidlund A., Sulyok M., Börjesson T., Krska R., Olsen M., Fredlund E. 2013. Deoxynivalenol and other selected Fusarium toxins in Swedish wheat - occurrence and correlation to specific Fusarium species. International Journal of Food Microbiology, 167: 284-291 https://doi.org/10.1016/j.ijfoodmicro.2013.07.002

Maresca M. 2013. From the gut to the brain: journey and pathophysiological effects on the food-associated trichothecene mycotoxin deoxynivalenol. Toxins, 5: 784-820 https://doi.org/10.3390/toxins5040784

Marin S., Ramos A. J., Cano-Sancho G., Sanchis V. 2013. Mycotoxins: occurrence, toxicology and exposure assessment. Food and Chemical Toxicology, 60: 218-237 https://doi.org/10.1016/j.fct.2013.07.047

Marroquín-Cardona A. G., Johnson N. M., Phillips T. D., Hayes A. W. 2014. Mycotoxins in a changing global environment $-\mathrm{a}$ review. Food and Chemical Toxicology, 69: $220-232$ https://doi.org/10.1016/j.fct.2014.04.025

McCormick S. P., Stanley A. M., Stover N. A., Alexander N. J. 2011. Trichothecenes: from simple to complex mycotoxins. Toxins. 3: 802-814 https://doi.org/10.3390/toxins3070802

Miller J. D. 2008. Mycotoxins in small grains and maize: old problems, new challenges. Food Additives and Contaminants. 25: 219-230 https://doi.org/10.1080/02652030701744520

Mostrom M. 2011. Trichothecenes and zearalenone. Gupta R. C. (ed.). Reproductive and developmental toxicology, p. 739-751 https://doi.org/10.1016/b978-0-12-382032-7.10054-2

Njobeh P. B., Dutton M. F., Koch S. H., Chuturgoon A. A., Stoev S. D., Mosonik J. S. 2010. Simultaneous occurrence of mycotoxins in human food commodities from Cameroon. Mycotoxin Research. 26: 47-57 https://doi.org/10.1007/s12550-009-0039-6

Nordkvist E., Häggblom P. 2014. Fusarium mycotoxin contamination of cereals and bedding straw at Swedish pig farms. Animal Feed Science and Technology, 198: 231-237 https://doi.org/10.1016/j.anifeedsci.2014.10.002

Pazderu K., Vepř́íková Z., Capouchová I., Konvalina P., Prokinová E., Janovská D., Škeř́ḱková A., Honsová H. 2016. Changes in the content of various Fusarium mycotoxins 
forms in germinating winter wheat and spring barley kernels. Plant. Soil and Environment. 62: 42-46 https://doi.org/10.17221/708/2015-PSE

Pestka J. J. 2007. Deoxynivalenol: toxicity, mechanisms and animal health risks. Animal Feed Science and Technology, 137: 283-298

https://doi.org/10.1016/j.anifeedsci.2007.06.006

Pestka J. J. 2008. Mechanisms of deoxynivalenol - induced gene expression and apoptosis. Food additives and Contaminants. Part A: Chemistry, Analysis, Control, Exposure and Risk Assessment. 25 (9): 1128-1140 https://doi.org/10.1080/02652030802056626

Pinton P., Tsybulskyy D., Lucioli J., Laffitte J., Callu P., Lyazhri F., Grosjean F., Bracarense A. P., Kolf-Clauw M., Oswald I. P. 2012. Toxicity of deoxyvalenol and its acetylated derivates on the intestine: differential effects on morphology, barrier function, tight junction proteins, and mitogen-activated protein kinases. Toxicological Sciences, 130 (1): $180-190$

https://doi.org/10.1093/toxsci/kfs239

Pospíchalová M. 2013. The results of mycotoxins monitoring in CISTA, mycotoxins and agricultural production: report of CISTA <http://eagri.cz/public/web/file/232493/ Pospichalova_seminar2013.pdf $>$ [accessed 1503 2016] (in Czech)

SCOOP. 2003. Collection of occurrence data of Fusarium toxins in food and assessment of dietary intake by the population of EU Member States <https://ec.europa. $\mathrm{eu} /$ food/sites/food/files/safety/docs/cs_contaminants catalogue_fusarium_task3210.pdf $>$ [accessed 1503 2016]
Speijers G. J. A., Speijers M. H. M. 2004. Combined toxic effect of mycotoxins. Toxicology Letters, 153: 91-98 https://doi.org/10.1016/j.toxlet.2004.04.046

Stanciu O., Banc R., Cozma A., Filip L., Miere D., Mañes J., Loghin F. 2015. Occurrence of Fusarium mycotoxins in wheat from Europe - a review. Acta Universitatis Cibiniensis, Series E: Food Technology, 19 (1): 35-60 https://doi.org/10.1515/aucft-2015-0005

Streit E., Schatzmayr G., Tassis P., Tzika E., Marin D., Taranu I., Tabuc C., Nicolau A., Aprodu I., Puel O., Oswald I. P. 2012. Current situation of mycotoxin contamination and co-occurrence in animal feed - focus on Eurone. Toxins, 4: 788-809 https://doi.org/10.3390/toxins4100788

Supronienė S., Sakalauskas S., MankevičienėA., Barčauskaite K., Jonavičienè A. 2016. Distribution of B type trichothecene producing Fusarium species in wheat grain and relation to mycotoxins DON and NIV concentrations. ZemdirbysteAgriculture, 103 (3): 281-288 https://doi.org/10.13080/z-a.2016.103.036

Wilson A., Simpson D., Chandler E., Jennings P., Nicholson P. 2004. Development of PCR assays for the detection and differentiation of Fusarium sporotrichoides and Fusarium langsethiae. FEMS Microbiology Letters. 233: 69-76 https://doi.org/10.1016/j.femsle.2004.01.040

Zinedine A., Soriano J. M., Moltó J. C., Mañes J. 2007. Review on the toxicity, occurrence, metabolism, detoxification, regulations and intake of zearalenone: an oestrogenic mycotoxin. Food and Chemical Toxicology, 45: 1-18 https://doi.org/10.1016/j.fct.2006.07.030

ISSN 1392-3196 / e-ISSN 2335-8947

Zemdirbyste-Agriculture, vol. 104, No. 2 (2017), p. 173-178

DOI $10.13080 / \mathrm{z}-\mathrm{a} .2017 .104 .022$

\title{
Slovakijoje užaugintų žieminių kviečių grūdų užterštumas Fusarium grybo mikotoksinais
}

\author{
M. Lacko-Bartošová ${ }^{1}$, J. Remža², L. Lacko-Bartošováa \\ 'Slovakijos žemès ūkio universitetas Nitroje \\ ${ }^{2}$ Slovakijos Respublikos veterinarijos ir maisto administracija \\ ${ }^{3}$ Slovakijos ekonomikos universitetas Bratislavoje
}

\section{Santrauka}

Nuėmus 2009-2010, 2010-2011 ir 2011-2012 vegetacijos metų derlių neperdirbtų žieminių kviečių užterštumas mikotoksinais buvo nustatytas Slovakijos Respublikoje. Mikotoksinų koncentracijos nustatytos efektyviosios skysčių chromatografijos (HPLC) metodu. Dažniausiai buvo aptinkamas Fusarium toksinas deoksinivalenolis (DON), nustatytas $85 \%$ mėginių. Jo koncentracija $2 \%$ mėginių viršijo maksimalų lygi, nustatytą Europos Sajungos reglamente (EC) 1881/2006. Nivalenolis (NIV) buvo nustatytas $63 \%$, T-2 - 73\%, HT-2 - $79 \%$ mèginių. Vidutinè DON koncentracija buvo 368,4 $\mathrm{g} \mathrm{kg}^{-1}$, NIV - 34,8 $\mathrm{g} \mathrm{kg}^{-1}, \mathrm{~T}-2-38,2 \mathrm{~g} \mathrm{~kg}^{-1}$, HT-2 - 29,9 $\mathrm{g} \mathrm{kg}^{-1}$. DON kartu su NIV buvo nustatyti 15,5\% mėginių, o jų paplitimas su kitais mikotoksinais sudaré papildomai 7,35\%. DON kartu su zearalenonu (ZEA) buvo nustatyti $25,9 \%$ mėginių.

Siekiant užkirsti kelią grūdų užterštumui žmonių sveikatai žalingomis mikotoksinų koncentracijomis, reikia taikyti kompleksą priemonių nuo gerosios žemdirbystès praktikos, į atsparumą nukreiptos selekcijos iki tinkamos maisto saugos kontrolès metodų ir įstatyminès bazès.

Reikšminiai žodžiai: kelių mikotoksinų paplitimas kartu, A ir B tipo trichotecenai, zearalenonas, žieminiai kviečiai. 